
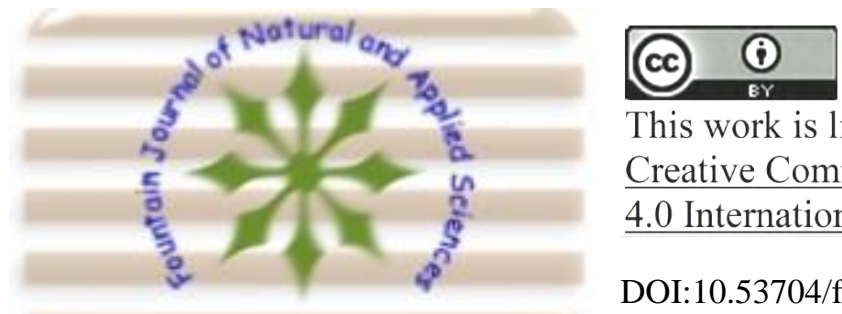

This work is licensed under Creative Commons Attribution 4.0 International License.

DOI:10.53704/fujnas.v10i1.333

A publication of College of Natural and Applied Sciences, Fountain University, Osogbo, Nigeria.

Journal homepage: www.fountainjournals.com

ISSN: 2354-337X(Online),2350-1863(Print);

\title{
Antibacterial Efficacies of Extracts of Lemon Grass (Cymbopogon citratus) on Some Clinical Microbial Isolates
}

\author{
${ }^{* 1}$ Ajijolakewu, A. K., ${ }^{1}$ Kazeem, M. O., ${ }^{1}$ Ahmed, R. N., ${ }^{1}$ Zakariyah, R. F., ${ }^{1}$ Agbabiaka, T. O., ${ }^{1}$ Ajide- \\ Bamigboye, N., ${ }^{1,2}$ Ayoola, S.A., ${ }^{1}$ Balogun, A. O. and ${ }^{1}$ Alhassan, $S$. \\ ${ }^{I}$ Department of Microbiology, Faculty of Life Sciences, University of Ilorin, Nigeria, PMB 1515 Ilorin. \\ ${ }^{2}$ Bioresources Development Centre, National Biotechnology Development Agency, Ogbomosho, Oyo State, Nigeria.
}

\begin{abstract}
The spread of new infections and the emergence of multidrug resistant strains of microorganisms necessitate the search for new antimicrobials with focus on plant extracts. In this study, the antimicrobial activity of the extracts (aqueous and ethanolic) of lemon grass known usually for bioactive essential oil (Cymbopogon citratus) was investigated in-vitro, against selected clinical isolates (Staphylococcus aureus, Escherichia coli, Enterococcus faecalis, Pseudomonas aeruginosa and Candida albicans). Antimicrobial efficacy of the extracts was assessed using the agar-well diffusion and broth-dilution techniques. The aqueous extract of $C$. citratus was more efficacious as it showed higher antimicrobial activity against all the test isolates at all tested concentrations. In contrast, only two of the test isolates; $P$. aeruginosa and $S$. aureus were susceptible to the ethanolic extract with minimum inhibitory (MIC) concentrations of $2 \mathrm{mg} / \mathrm{ml}$ (against $S$. aureus) and $12.5 \mathrm{mg} / \mathrm{ml}$ (against $P$. aeruginosa). The MIC of the aqueous extract were $(\mathrm{mg} / \mathrm{ml}): 2,6.25,12.5,25$ and 50 against $S$. aureus, E. faecalis, $P$. aeruginosa, $E$. coli and $C$. albicans respectively. Meanwhile, both the aqueous and ethanolic extracts of C. citratus exerted only a bacteriostatic effect against the five test isolates at all concentrations. Quantitative phytochemical screening of the two extracts revealed the presence of more concentration of active compounds in the aqueous extract than the ethanolic extract which plausibly accounts for its greater antimicrobial activity. This study has shown that, in difference to the use of its conventional essential oil, solvent extraction of Cymbopogon citratus is also a potent source of efficacious antimicrobials. Further works to determine the respective mechanisms of action(s) of the extracts' active principle is being projected.
\end{abstract}

Keywords: Lemon grass, clinical isolates, antimicrobial efficacies, bioactive compounds

\section{Introduction}

Antibiotics are regarded as "miracle drugs" (Levy, 2013) because of their ability to greatly reduce mortality and morbidity due to infectious diseases (Zaffiri et al., 2012). Infectious diseases are known life-threatening ailment (Leeb, 2004) with overall impact on the society (Zaffiri et al., 2012).

*Corresponding author: +2348066980264

Email address: ajijolakewu.ak@unilorin.edu.ng 
Infectious diseases are known life-threatening ailment (Leeb, 2004) with overall impact on the society (Zaffiri et al., 2012). However, this success is recently being reversed due to increased antibiotic resistance in vivo. Antibiotic resistance is, mostly, due to human anthropogenic activities ranging from the over-use (Llor \& Bjerrum, 2014) and misuse (El Salabi et al., 2013) of antibiotics which often lead to treatment failure (Woolhouse $e t$ al., 2016) as direct consequence (Llor \& Bjerrum, 2014). Misuse and over-use are the major vehicles driving antibiotic pressures which ultimately accelerates the mechanisms of resistance in previously susceptible bacteria and/or the emergence of a new resistant strains. The problem of antibiotic resistance is of immense magnitude that it is now recognized as belonging to the category of critical dangers to humanity (Llor \& Bjerrum, 2014). This is not overly exaggerated as it ranks according to Santajit \& Indrawattana (2016) in the top three global public health threat. The significance of the problem and the urgency of solutions therefore necessitate a search for alternative sources of antimicrobials from verifiable ancient therapeutic system which employ plant sources often referred as nature's pharmacy (Pouliot, 2011). Plants, has throughout human history provided drugs to cure ailments (Cragg \& Newman, 2013) and supported healthy growth of man and animals (Hasan \& Sadiq, 2020). Rural dwellers and about $34 \%$ of the world's population, even now, largely depend on plants (Pouliot, 2011). Lemongrass, Cymbopogon citratus, is one such potent alternative source of antimicrobials (Ekpenyong et al., 2015) which is widely cultivated globally (Francisco et al., 2014). It has been reported for wide range of activities against several diseases-causing organisms (Figueirinha et al., 2008; Francisco et al., 2014; Francisco et al., 2011; Naik et al., 2010; Shah et al., 2012). Researches on the use of lemon grass as potential antimicrobial agent have been focused majorly on the use of its essential oils (Adukwu et al., 2016; De Silva et al., 2017; Naik et al., 2010). While studies on the use of its other equally potent but extractible components are, despite high potency of reported activities, very few or relatively insignificant. For instance, respective reports by Adeneye \& Agbaje
(2007) and Ekpenyong et al. (2015) have shown the activities of different extracts of Cymbopogon citratus as antibacterial, antimalarial, antifungal, and antiprotozoal. On the other hand, details of the components and mode of actions of the essential oil components of $C$. citratus have been well elucidated (Adukwu et al., 2016; Katsukawa et al., 2010). For instance, Katsukawa and co-researchers (Katsukawa et al., 2010) established that essential oil from lemon grass acts on microorganism by suppressing the protein expression. Through cellbased transfection assay, they postulated that citral, a major component of lemon grass essential oil suppressed cyclooxygenase (COX-2) which is a key enzyme for prostaglandin synthesis and also an activator of peroxisome proliferator-activated receptor (PPAR). While prostaglandins are group of lipids made at sites of tissue damage or injurious microbial infection for quick repairs, PPAR is a molecular target for "lifestyle-related" diseases. They further argued that citral also suppressed both LPS-induced COX-2 mRNA and protein expression, albeit dose-dependently. However, there is scarcely a report on the determination of the exact active principles of the non-oil extract of this plant; and where exist, there is no report on its mechanism of action, a basis to understand the logical therapeutic and nutritional uses of the drug. This study thus investigated the phytochemical composition and the antimicrobial activity of aqueous and ethanolic extracts of $C$. citratus leaves against selected clinical isolates (Escherichia coli, Staphylococcus aureus, Pseudomonas aeruginosa, Enterococcus faecalis, and Candida albicans) which currently form some of the most formidable multidrug resistant pathogens (Santajit \& Indrawattana, 2016).

\section{Materials and Methods}

The $C$. citratus leaves were obtained from a local herb store in Ilorin, Kwara state, Nigeria $\left(8.4799^{\circ}\right.$ $\left.\mathrm{N}, 4.5418^{\circ} \mathrm{E}\right)$. The plant sample was identified visually and confirmed at the Herbarium unit of Department of Plant Biology, University of Ilorin and registered under the voucher number UILH/001/2019/949. The leaves were sun-dried, grounded into a fine powder and thereafter kept in 
sterile plastic containers until further use at room temperature $\left(28 \pm 1^{\circ} \mathrm{C}\right)$.

\section{Test Organisms}

Five test isolates viz. Staphylococcus aureus, Escherichia coli, Pseudomonas aeruginosa, Enterococcus faecalis and Candida albicans were obtained from the stock culture of the Department of Microbiology, University of Ilorin Teaching Hospital, Ilorin, Nigeria. Before use, each organism was grown on respective selective media and were all gram-stained (except Candida albicans) to confirm the respective identity as follows: Staphylococcus aureus (yellow colonies on Mannitol Salt Agar), Escherichia coli (green metallic sheen on Eosin Methylene Blue), Pseudomonas aeruginosa (green colonies on CLED Agar), Enterococcus faecalis (black zones around colonies on Bile Esculin Agar) and Candida albicans (cream pasty convex on Sabouraud Dextrose Agar). Purity of the culture was checked at regular intervals according to standard protocols.

\section{Preparation of Extracts}

Aqueous extract of lemongrass was prepared following the protocol described by Balakrishnan et al. (2014). On the other hand, the ethanolic extract was prepared by soaking $50 \mathrm{~g}$ of finely cut lemongrass leaves in $500 \mathrm{~mL}$ of ethanol $(95 \%)$ at room temperature and kept on a shaker (150 rpm) for 36 hours in an air-tight container as earlier described by Ajijolakewu \& Awarun (2015). The aqueous and ethanolic extracts obtained were filtered at first using clean muslin cloth and afterwards with Whatman No 1 filter paper. Both filtrates were respectively evaporated to dryness and stored in sterile, air-tight cap bottles at room temperature $\left(29^{\circ} \mathrm{C} \pm 1^{\circ} \mathrm{C}\right)$ until further use.

\section{Reconstitution and Preparation of Stock Concentration}

Dimethyl sulfoxide (DMSO) was used to prepare stock concentration from all extracts. Two grams of extracts were dissolved in $10 \mathrm{~mL}$ of solvent to obtain the general stock at a concentration of 200 $\mathrm{mg} / \mathrm{ml}$. Varying concentration were prepared from the main stock in the following proportions 100,50, $25,12.5,6.25$ and $2 \mathrm{mg} / \mathrm{ml}$ by diluting with appropriate volume of DMSO. The different concentrations were stored in air-tight bottles after proper agitation until used.

\section{Determination of Antimicrobial Activity}

Inocula of the test isolates were standardized as described by Singh et al. (2010) to quantitatively asses the antimicrobial activity of the extracts. Inoculum standardization was done by making up each microbial suspension to equal the absorbance $(530 \mathrm{~nm})$ of $0.5 \mathrm{McFarland}$ standard $\left(300 \times 10^{6}\right.$ $\mathrm{cfu} / \mathrm{ml}$ ) on UV spectrophotometer. The agar well diffusion technique as described by Ajijolakewu \& Awarun (2015) was adopted to determine the antimicrobial activities of the extracts. In this method, $0.1 \mathrm{~mL}$ of the respective standardized Inocula was spread on sterile Mueller Hinton agar plate with using sterile glass spreader. Agar plates were allowed to dry and agar wells $(6.0 \mathrm{~mm}$ diameter) were bored aseptically using sterile corkborer. The wells were bored according to the number of intended extract concentrations in addition to an extra used as negative control. Subsequently, $0.1 \mathrm{~mL}$ of each extract concentrations was introduced unto the wells and thereafter incubated at $37{ }^{\circ} \mathrm{C}$ for 24 hours. Streptomycin was used as positive control.

Antimicrobial activity of the extracts was determined by measuring the zones of inhibition produced around the wells. The diameter of the zones indicated the degree of susceptibility of the test organisms.

\section{Determination of Minimum Inhibitory Concentration (MIC)}

Minimum inhibitory concentration was determined following the protocol described by Ajijolakewu \& Awarun (2015) with slight modification. One milliliter $(1.0 \mathrm{~mL})$ of all extracts at concentrations 200, 100, 50, 25, 12.5, 6.25 and $2 \mathrm{mg} / \mathrm{mL}$ were added into $9 \mathrm{~mL}$ of sterile nutrient broth in different test tubes. Subsequently, $0.1 \mathrm{~mL}$ of an 18-hour old culture broth adjusted to $0.5 \mathrm{McF}$ arland turbidity standard was inoculated into each test tube. Two controls (one consisting of a combination of plant extracts at various concentrations plus the nutrient broth without inoculum in the same proportion as the experiment and a blank tube consisting of only 
sterile broth) were set. The tubes were incubated at $37^{\circ} \mathrm{C}$ for 24 hours and observed. Upon observation, the tube with the lowest concentration (highest dilution) that had no detectable growth when compared with the control tubes using both visual and spectrophotometer observations was taken according to the protocol of Dahiya \& Purkayastha (2012) as the minimum inhibitory concentration (MIC).

\section{Determination of Minimum Bactericidal Concentration (MBC)}

MBC was determined as described by Ajijolakewu \& Awarun (2015). The Minimum Bactericidal Concentration of the extracts was evaluated by subculturing test solutions which showed no turbidity after 24 hrs incubation (i.e. no detectable growth) onto a recovery medium (a fresh Nutrient Agar plates) and incubated further for 24 hours. Appearance or absence of growth on the fresh nutrient agar plates suggested either bacteriostatic or bactericidal effect respectively

\section{Phytochemical Screening of Extracts}

The extracts were screened for the presence of tannins, saponins, flavonoids, steroids, terpenes, terpenoids, glycosides, alkaloids and phenol as described by Madhu et al. (2016).

\section{Statistical Analysis}

Data were expressed as mean and standard deviation of three independent replicates based on statistical analysis using IBM SPSS Statistics V22.

\section{Results and Discussion}

This study investigated the antimicrobial properties of aqueous and ethanolic extracts of Cymbopogon citratus leaves against selected clinical isolates involving a fungus and four bacterial species so as to generate data to be used as a logical leap for the determination of the plant's most potent active principle(s) and for a subsequent elucidation of their various modes of action against test organisms which, as far as we know, have not been previously described in any report. Findings in this study are hereby presented below:

\section{Quantitative Analysis of Phytochemical Constituents}

Table 1 shows the quantitative ranking of the phytochemicals present in both aqueous and ethanolic extracts of Cymbopogon citratus respectively. Except for glycosides, the generally known and important plant's bioactive compounds such as, tannins, saponins, alkaloids and terpenoids were present in both the aqueous and ethanolic extracts albeit in different amounts. The aqueous extracts showed preponderance of the important components (e.g. terpenoids, triterpenes and flavonoids) as against the ethanolic extract which was only able to extract more of the inconsequential saponins and steroids on a comparative scale with aqueous extract (Table 1). The reasons for the obvious disparity are immediately unknown but may be due to differences in the polarity of the two solvents. Water is more polar than ethanol, hence the greater amounts of component amounts. Another reason could be the insufficiency in the volume or quantity of ethanol used during extraction, a factor which is being considered for further research. Generally, these bioactive compounds have been demonstrated to be responsible for the antimicrobial activity of medicinal plants. For instance, phenolics generally classified into tannins, phenolic acids, flavonoids among other categories (Tacouri et al., 2013) exerts antioxidant effects which are known to disrupt cell enzyme activities and to cause disintegration of the outer membrane of microorganisms (Lacombe et al., 2010). Phenolics have also been shown (Espín et al., 2017) to modulate healthy gut microbiota thereby establishing a scientific basis for the oral administration of lemongrass decoctions as used in folk medicine. Saponins are a category of glycosides with fat-soluble core (aglycone) in the form of a triterpenoid (C-30) or alkaloid steroid (C27) (Hassan et al., 2010b). Although, with yet unclear mechanism of antibacterial activity, saponins are known to generally express a doseresponse effect on all bacterial species even though some glucosidases produced by Gram negative bacteria have been reported to be capable of saponins degradation (Hassan et al., 2010a). 
Table 1: Quantification of Phytochemical Constituents of the Aqueous and Ethanolic Extracts of Cymbopogon citratus

\begin{tabular}{lll}
\hline Phytochemicals & $\begin{array}{l}\text { Aqueous } \\
\text { Extract } \\
(\mathbf{m g} / \mathbf{m L})\end{array}$ & $\begin{array}{l}\text { Ethanolic } \\
\text { extract } \\
(\mathbf{m g} / \mathbf{m L})\end{array}$ \\
\hline Phenolics & $0.78 \pm 0.003$ & $0.94 \pm 0.001$ \\
Flavonoid & $1.45 \pm 0.000$ & $0.79 \pm 0.000$ \\
Saponins & $0.08 \pm 0.000$ & $1.33 \pm 0.000$ \\
Glycoside & $0.00 \pm 0.000$ & $0.00 \pm 0.000$ \\
Alkaloid & $1.49 \pm 0.004$ & $1.46 \pm 0.026$ \\
Steroids & $1.47 \pm 0.000$ & $2.19 \pm 0.059$ \\
Tannin & $0.33 \pm 0.016$ & $0.20 \pm 0.004$ \\
Triterpene & $7.13 \pm 0.170$ & $4.07 \pm 0.270$ \\
Terpenoids & $3.90 \pm 1.530$ & $2.17 \pm 0.650$ \\
\hline
\end{tabular}

Data are expressed as mean + standard deviation of three independent replicates.

As shown in Table 1, although in different quantities, both the aqueous and ethanolic extracts exhibited similar fractional components to enhance the modulation of their respective antimicrobial activities.

\section{Antimicrobial Activity of Extracts}

Tables $2 \mathrm{a} \& 2 \mathrm{~b}$ shows the results of the antimicrobial efficacies of the aqueous (Table 2a) and ethanolic (Table 2b) extracts of $C$. citratus. Varying degrees of growth inhibition were expressed by the respective extracts against the test isolates.

Table 2: Antimicrobial Activity of Aqueous and Ethanolic Extracts of Cymbopogon Citratus against Selected Clinical Isolates

a. Aqueous Extract of Cymbopogon citratus

\begin{tabular}{cccccc}
\hline $\begin{array}{c}\text { Concentration } \\
(\mathbf{m g} / \mathbf{m l})\end{array}$ & \multicolumn{4}{c}{ Diameter of Zones of inhibition $(\mathbf{m m})$ on the representative clinical isolates } \\
& $\begin{array}{c}\text { Candida } \\
\text { albicans }\end{array}$ & $\begin{array}{c}\text { Pseudomonas } \\
\text { aeruginosa }\end{array}$ & $\begin{array}{c}\text { Enterococcus } \\
\text { faecalis }\end{array}$ & $\begin{array}{c}\text { Escherichia } \\
\text { coli }\end{array}$ & $\begin{array}{c}\text { Staphylococcus } \\
\text { aureus }\end{array}$ \\
\hline 2.00 & - & - & - & - & $2 \pm 0$ \\
6.25 & - & $7 \pm 2$ & $7 \pm 2$ & - & $3 \pm 0$ \\
12.50 & - & $8 \pm 0$ & $9 \pm 1$ & $5 \pm 0$ & $5 \pm 1$ \\
25.00 & - & $15 \pm 2$ & $10 \pm 2$ & $9 \pm 1$ & $6 \pm 0$ \\
50.00 & $4 \pm 0$ & $17 \pm 1$ & $10 \pm 0$ & $13 \pm 2$ & $15 \pm 2$ \\
100.00 & $10 \pm 1$ & $19 \pm 2$ & $14 \pm 1$ & $14 \pm 0$ & $15 \pm 1$ \\
200.00 & $20 \pm 2$ & $21 \pm 2$ & $19 \pm 2$ & $21 \pm 2$ & $25 \pm 2$ \\
\hline
\end{tabular}

b. Ethanolic Extract of Cymbopogon citratus

\begin{tabular}{cccccc}
\hline $\begin{array}{c}\text { Concentration } \\
(\mathbf{m g} / \mathbf{m l})\end{array}$ & \multicolumn{5}{c}{ Diameter of Zones of inhibition $(\mathbf{m m})$ on the representative clinical isolates } \\
& $\begin{array}{c}\text { Candida } \\
\text { albicans }\end{array}$ & $\begin{array}{c}\text { Pseudomonas } \\
\text { aeruginosa }\end{array}$ & $\begin{array}{c}\text { Enterococcus } \\
\text { faecalis }\end{array}$ & $\begin{array}{c}\text { Escherichia } \\
\text { coli }\end{array}$ & $\begin{array}{c}\text { Staphylococcus } \\
\text { aureus }\end{array}$ \\
\hline 2 & - & - & - & - & - \\
6.25 & - & - & - & - & - \\
12.5 & - & $3 \pm 0$ & - & - & - \\
25 & - & $8.5 \pm 1$ & - & - & - \\
50 & - & $12 \pm 2$ & - & - & - \\
100 & - & $16 \pm 1$ & - & - & - \\
200 & - & $19 \pm 2$ & - & - & $11 \pm 2$ \\
\hline
\end{tabular}


As shown in Table 2a, S. aureus was the most susceptible organism to the aqueous extract of $C$. citratus expressing different degree of sensitivity to various concentrations of the extract used. All other species were also susceptible to a fair concentration $(6.25 \mathrm{mg} / \mathrm{ml})$ of aqueous extract except E. coli whose susceptibility was observed at concentration $12.5 \mathrm{mg} / \mathrm{ml}$ of the extract. On the other hand, the unicellular fungus Candida albicans is the least susceptible organism eliciting noticeable susceptibility at $50 \mathrm{mg} / \mathrm{ml}$ of the aqueous extract. Table $2 \mathrm{~b}$ shows the susceptibility patterns of test isolates to ethanolic extracts of $C$. citratus. The isolate $P$. aeruginosa was the only susceptible organism at concentration between 12.5 and 200 $\mathrm{mg} / \mathrm{ml}$ of the extract. All other isolates showed resistance except $S$. aureus which was only susceptible at higher concentration of $200 \mathrm{mg} / \mathrm{ml}$. Shah et al. (2011) had earlier reported the efficacy of aqueous and ethanolic extracts of $C$. citratus against several medically important microorganisms including species of those used in this study.

Comparatively, the aqueous extract was most potent against all the tested isolates (Table 2a) compared to the ethanolic extract (Table 2b) of Lemon grass (Cymbopogon citratus). The broader spectrum of activity of the aqueous extract is most probably due to the preponderance or higher amount of the its component phytochemicals (Table 2) compared to the ethanolic extract. This finding is however, in contrary to the report of Dahiya \& Purkayastha (2012) who reported a consistent and potent activity for ethanolic and methanolic extracts over extracts of hexane, chloroform, methanol, ethanol and aqueous. Other researchers (Fagbemi et al., 2009; Joshua et al., 2012) had also observed higher potency of the ethanolic extracts of $c$. citratus compared with other forms of extraction. However, this puzzling observation in this study could justifiably be due to the higher polarity of water in comparison to the less polar organic ethanol. Moreover, the variation could also be due to difference in geographic and climatic conditions which is established to affect phytochemical composition of plants as earlier observed and reported by Shah et al. (2011). Moreover, Since the quantity of phytochemicals present is a function of its efficacy for antimicrobial effect, it is plausible to tie the better antimicrobial effect of aqueous to flavonoids, glycosides, alkaloids, triterpenes, and terpenoids which were higher in the aqueous compared with the ethanolic extracts.

Results of antimicrobial susceptibility testing of the aqueous extract (Table 2a) and the ethanolic extract where applicable (Table 2b) established an effect of concentration gradient on the susceptibility pattern in all test isolates. In Table $2 \mathrm{a}$, the rate of microbial inhibition (represented by the zone of inhibition) is proportional to the concentration of the extract. The highest concentration $(200 \mathrm{mg} / \mathrm{ml})$ was the most efficacious against all the organism while the lowest effective concentration was organismdependent. The least susceptible organism was $C$. albicans with the lowest effective concentration 50 $\mathrm{mg} / \mathrm{ml}$. Staphylococcus aureus was most susceptible such that a $2 \mathrm{mg} / \mathrm{ml}$ concentration of the aqueous extract successfully inhibited its growth to a certain degree i.e. $2 \mathrm{~mm}$ (Table $2 \mathrm{a}$ ). On the other hand, nearly all the tested isolates were resistant to the ethanol extract of $C$. citratus (Table 2b). Even though, Staphylococcus aureus was also susceptible (only at $200 \mathrm{mg} / \mathrm{ml}$ ); it was only Pseudomonas aeruginosa which showed obvious susceptibility pattern at extract concentrations between $25 \mathrm{mg} / \mathrm{ml} \& 200 \mathrm{mg} / \mathrm{ml}$. Others, $C$. albicans, Enterococcus faecalis, and Escherichia coli are entirely resistant across concentrations.

Comparatively, the data presented in Tables $2 \mathrm{a} \& \mathrm{~b}$ show that the aqueous extract of $C$. citratus is generally more efficacious performing better than the ethanolic extract. Also, independent of the type of susceptible organisms, both extracts exerted a dose-response susceptibility (Table 2a); and only Psuedomonas aeruginosa was the only major organism susceptible to the ethanolic extract (Table $2 b)$. This is spectacular since previous report by Naik et al. (2010) has concluded that (essential) oil extract from lemon grass was ineffective against $P$. aeruginosa. However, Relative to the finding here, diseases to which $P$. aeruginosa has been implicated can easily be treated using the aqueous extract from $\mathrm{ABU}$.

Further, as shown in Table 2a, Candida albicans, a fungus, requires particularly higher extract 
concentration before inhibition. This was followed by all Gram negatives isolates, while $S$. aureus was particularly susceptible at all concentrations tested. This hierarchy in susceptibility may be attributed to the distinct difference in the cell types. Naik et al. (2010) has also reported that gram positive organisms are more susceptible to lemon grass oil than gram negatives. This is more so that clinical fungal isolates, Gram negative bacteria, and then Gram positive pathogens rank in virulence in descending order (Abe et al., 2010).

\section{Minimum Inhibitory Concentrations (MIC) and} Maximum Bactericidal Concentrations

Table 3 show the minimum inhibitory (MIC) and maximum bactericidal (MBC) concentration values of the respective extracts. As shown, both extracts showed no bactericidal property on all the tested isolates. Based on the larger inhibitory activities, MIC values were demonstrated and recorded for the aqueous extract on all the tested isolates but were recorded only for two isolates on which the ethanolic extract was effective. The MIC values were organism as well as extraction-typedepended. For instance, MIC value of $S$. aureus using aqueous extract was $2 \mathrm{mg} / \mathrm{ml}$ but was 150 $\mathrm{mg} / \mathrm{ml}$ using ethanolic extract. On the other hand, the MIC on C. albicans is $50 \mathrm{mg} / \mathrm{ml}$ against the 2 $\mathrm{mg} / \mathrm{ml}$ or $6.25 \mathrm{mg} / \mathrm{ml}$ exhibited by $S$. aureus and $E$. faecalis (Table 3). No MBC value was recorded as there was regrowth across all the concentrations tested as shown in Table 3.

Minimum inhibitory Concentration (MIC) of the extracts of Cymbopogon citratus

\begin{tabular}{|c|c|c|c|c|}
\hline \multirow{2}{*}{$\begin{array}{l}\text { Organism } \\
\mathrm{s}\end{array}$} & \multicolumn{2}{|c|}{ MIC (mg/ml) } & \multicolumn{2}{|c|}{ MBC (mg/ml) } \\
\hline & $\begin{array}{c}\text { Aqueou } \\
\text { s } \\
\text { Extract }\end{array}$ & $\begin{array}{l}\text { Ethanoli } \\
\text { c Extract }\end{array}$ & $\begin{array}{c}\text { Aqueou } \\
\text { s } \\
\text { Extract }\end{array}$ & $\begin{array}{l}\text { Ethanoli } \\
\mathrm{c} \\
\text { Extract }\end{array}$ \\
\hline S. aureus & 2 & 150 & - & - \\
\hline $\begin{array}{l}P . \\
\text { aeruginosa }\end{array}$ & 12.5 & 12.5 & - & - \\
\hline E. faecalis & 6.25 & - & - & - \\
\hline E. coli & 25 & - & - & - \\
\hline C. albicans & 50 & - & - & - \\
\hline
\end{tabular}

The absence of biocidal effect points to the presence of resistance mechanisms within the test isolates that overturns the inhibitory activity of the extracts. In previous studies, drug inactivation /alteration of target sites, limited intracellular concentration of antimicrobial, agent binding site modification, biofilm formation (Santajit \& Indrawattana, 2016), ribosomal protectionencoding genes, efflux pump (Castanheira et al., 2014), alteration of responses towards cellular stress (Shapiro et al., 2011) have been reported as resistance mechanisms commonly exhibited by most the organisms used in this study. In further studies, the specific resistance mechanism will be studied in addition to knowing the mechanism of actions of the active phytochemicals of the lemon grass. Other extraction methods (non-polar) will also be tried in subsequent researches to determine the likely presence of other important phytochemicals.

\section{Conclusion}

Aqueous and ethanolic extracts of lemon grass (Cymbopogon citratus) have been used to demonstrate its potency against selected clinical isolates thus justifying its use in traditional medicine, as its essential oil, for treating different diseases associated with the tested susceptible isolates of both superficial and enteric origins. While both extracts exerted a dose-response susceptibility the susceptible organisms, the aqueous extract of $C$. citratus is generally more efficacious than the ethanolic extract of same. Work is still on to optimize concentration towards the determination of the biocidal concentration, the mechanism of action of synergistic effect of the plant's extract active principles and to understand the mode of microbial resistance. Further toxicological, purification and identification studies would be carried out to investigate the general effects of the use of lemon grass for drug development.

\section{References}

Abe, R., Oda, S., Sadahiro, T., Nakamura, M., Hirayama, Y., Tateishi, Y., Shinozaki, K. \& Hirasawa, H. (2010). Gram-negative bacteremia induces greater magnitude of inflammatory response than Gram-positive bacteremia. Critical Care, 14(2), R27.

Adeneye, A.A. \& Agbaje, E.O. (2007). Hypoglycemic and hypolipidemic effects of 
fresh leaf aqueous extract of Cymbopogon citratus Stapf. in rats. Journal of Ethnopharmacology, 112(3), 440-444.

Adukwu, E.C., Bowles, M., Edwards-Jones, V. \& Bone, H. (2016). Antimicrobial activity, cytotoxicity and chemical analysis of lemongrass essential oil (Cymbopogon flexuosus) and pure citral. Applied microbiology and biotechnology, 100(22), 9619-9627.

Ajijolakewu, K.A. \& Awarun, F.J. (2015). Comparative Antibacterial Efficacy of Vitellaria paradoxa (Shea Butter Tree) Extracts Against Some Clinical Bacterial Isolates. Notulae Scientia Biologicae, 7(3), 264-268.

Balakrishnan, B., Paramasivam, S. \& Arulkumar, A. (2014). Evaluation of the lemongrass plant (Cymbopogon citratus) extracted in different solvents for antioxidant and antibacterial activity against human pathogens. Asian Pacific Journal of Tropical Disease, 4(1), S134-S139.

Castanheira, M., Mendes, R.E. \& Jones, R.N. (2014). Update on Acinetobacter Species: Mechanisms of Antimicrobial Resistance and Contemporary In Vitro Activity of Minocycline and Other Treatment Options. Clinical Infectious Diseases, 59(suppl_6), S367-S373.

Cragg, G.M. \& Newman, D.J. (2013). Natural products: a continuing source of novel drug leads. Biochimica et Biophysica Acta, 1830(6), 3670-3695.

Dahiya, P. \& Purkayastha, S. (2012). Phytochemical Screening and Antimicrobial Activity of Some Medicinal Plants against Multi-drug Resistant Bacteria from Clinical Isolates. Indian Journal of pharmaceutical sciences, 74(5), 443-450.

De Silva, B.C.J., Jung, W.-G., Hossain, S., Wimalasena, S.H.M.P., Pathirana, H.N.K.S. \& Heo, G.-J. (2017). Antimicrobial property of lemongrass (Cymbopogon citratus) oil against pathogenic bacteria isolated from pet turtles. Laboratory animal research, 33(2), 84-91.

Ekpenyong, C.E., Akpan, E. \& Nyoh, A. (2015). Ethnopharmacology, phytochemistry, and biological activities of Cymbopogon citratus (DC.) Stapf extracts. Chinese Journal of Natural Medicines, 13(5), 321-337.
El Salabi, A., Walsh, T.R. \& Chouchani, C. (2013). Extended spectrum $\quad \beta$-lactamases, carbapenemases and mobile genetic elements responsible for antibiotics resistance in Gramnegative bacteria. Critical Reviews in Microbiology, 39(2), 113-122.

Espín, J.C., González-Sarrías, A. \& TomásBarberán, F.A. (2017). The gut microbiota: A key factor in the therapeutic effects of (poly)phenols. Biochemical Pharmacology, 139, 82-93.

Fagbemi, J.F., Ugoji, E., Adenipekun, T. \& Adelowotan, O. (2009). Evaluation of the antimicrobial properties of unripe banana (Musa sapientum L.), lemon grass (Cymbopogon citratus S.) and turmeric (Curcuma longa L.) on pathogens. African Journal of Biotechnology, $8(7)$.

Figueirinha, A., Paranhos, A., Pérez-Alonso, J.J., Santos-Buelga, C. \& Batista, M.T. (2008). Cymbopogon citratus leaves: Characterization of flavonoids by HPLC-PDA-ESI/MS/MS and an approach to their potential as a source of bioactive polyphenols. Food Chemistry, 110(3), 718-728.

Francisco, V., Figueirinha, A., Costa, G., Liberal, J., Lopes, M.C., García-Rodríguez, C., Geraldes, C.F.G.C., Cruz, M.T. \& Batista, M.T. (2014). Chemical characterization and antiinflammatory activity of luteolin glycosides isolated from lemongrass. Journal of Functional Foods, 10, 436-443.

Francisco, V., Figueirinha, A., Neves, B.M., García-Rodríguez, C., Lopes, M.C., Cruz, M.T. \& Batista, M.T. (2011). Cymbopogon citratus as source of new and safe anti-inflammatory drugs: Bio-guided assay using lipopolysaccharidestimulated macrophages. Journal of Ethnopharmacology, 133(2), 818-827.

Hasan H. I. \& Sadeq, S.A. (2020). Effect of peppermint supplementation as powder or extract on broiler performance, serum biochemical content and gut health under e coli challenge. Iraqi Journal of Agricultural Sciences, $51(1)$ https://doi.org/10.36103/ijas.v51i1.928

Hassan, S., Haq, A., Byrd, J., Berhow, M., Cartwright, A. \& Bailey, C. (2010a). 
Haemolytic and antimicrobial activities of saponin-rich extracts from guar meal. Food Chemistry, 119(2), 600-605.

Hassan, S.M., Byrd, J.A., Cartwright, A.L. \& Bailey, C.A. (2010b). Hemolytic and Antimicrobial Activities Differ among Saponinrich Extracts from Guar, Quillaja, Yucca, and Soybean. Applied Biochemistry and Biotechnology, 162(4), 1008-1017.

Joshua, A.A., Usunomena, U., Lanre, A.B., Amenze, O. \& Gabriel, O.A. (2012). Comparative studies on the chemical composition and antimicrobial activities of the ethanolic extracts of Lemon grass leaves and stems. Asian Journal of Medical Sciences, 4(4), 145-148.

Katsukawa, M., Nakata, R., Takizawa, Y., Hori, K., Takahashi, S. \& Inoue, H. (2010). Citral, a component of lemongrass oil, activates PPAR $\alpha$ and $\gamma$ and suppresses COX-2 expression. Biochimica et Biophysica Acta (BBA) Molecular and Cell Biology of Lipids, 1801(11), 1214-1220.

Lacombe, A., Wu, V.C.H., Tyler, S. \& Edwards, K. (2010). Antimicrobial action of the American cranberry constituents; phenolics, anthocyanins, and organic acids, against Escherichia coli O157:H7. International Journal of Food Microbiology, 139(1), 102-107.

Leeb, M. (2004). A shot in the arm. Nature, 431(7011), 892-893.

Levy, S.B. (2013). The antibiotic paradox: how miracle drugs are destroying the miracle. Springer Science + Business Media LLC US. ISBN 978-1-4899-6042-9. DOI 10.1007/978-14899-6042-9

Llor, C. \& Bjerrum, L. (2014). Antimicrobial resistance: risk associated with antibiotic overuse and initiatives to reduce the problem. Therapeutic Advances in Drug Safety, 5(6), 229241.

Madhu, M., Sailaja, V., Satyadev, T. \& Satyanarayana, M. (2016). Quantitative phytochemical analysis of selected medicinal plant species by using various organic solvents. Journal of Pharmacognosy and Phytochemistry, 5(2), 25.
Naik, M.I., Fomda, B.A., Jaykumar, E. \& Bhat,A. (2010). Antibacterial activity of lemongrass (Cymbopogon citratus) oil against some selected pathogenic bacterias. Asian Pacific Journal of Tropical Medicine, 3(7), 535-538.

Pouliot, M. 2011. Relying on nature's pharmacy in rural Burkina Faso: Empirical evidence of the determinants of traditional medicine consumption. Social Science \& Medicine, 73(10), 1498-1507.

Santajit, S. \& Indrawattana, N. (2016). Mechanisms of Antimicrobial Resistance in ESKAPE Pathogens. BioMed research international, 2016, 2475067-2475067.

Shah, G., Kaur, M., Dhabiliya, F. \& Shri, R. (2012). Pharmacognostic Standardization of Cymbopogon citratus (dc.) stapf leaves. Pharmacognosy Journal, 4(29), 19-25.

Shah, G., Shri, R., Panchal, V., Sharma, N., Singh, B. \& Mann, A.S. (2011). Scientific basis for the therapeutic use of Cymbopogon citratus, stapf (Lemon grass). Journal of advanced Pharmaceutical Technology \& Research, 2(1), 3-8.

Shapiro, R.S., Robbins, N. \& Cowen, L.E. (2011). Regulatory Circuitry Governing Fungal Development, Drug Resistance, and Disease. Microbiology and Molecular Biology Reviews, 75(2), 213-267.

Singh, M., Khatoon, S., Singh, S., Kumar, V., Rawat, A.K.S. \& Mehrotra, S. (2010). Antimicrobial screening of ethnobotanically important stem bark of medicinal plants. Pharmacognosy research, 2(4), 254-257.

Tacouri, D.D., Ramful-Baboolall, D. \& Puchooa, D. (2013). In vitro bioactivity and phytochemical screening of selected spices used in Mauritian foods. Asian Pacific Journal of Tropical Disease, 3(4), 253-261.

Woolhouse, M., Waugh, C., Perry, M.R. \& Nair, H. (2016). Global disease burden due to antibiotic resistance - state of the evidence. Journal of global health, 6(1), 010306-010306.

Zaffiri, L., Gardner, J. \& Toledo-Pereyra, L.H. (2012). History of Antibiotics. From Salvarsan to Cephalosporins. Journal of Investigative Surgery, 25(2), 67-77. 